\title{
Pomiędzy anatomia animata i physiologia experimentalis
}

Słowa kluczowe: historia anatomii; historia fizjologii; anatomia animata; Albrecht von Haller

Albrecht von Haller (1708-1777), postrzegany jako jeden z twórców podstaw współczesnej fizjologii, używa pojęcia anatomia animata dla określenia swoich zainteresowań badawczych wiążących się z funkcjami życiowymi organizmów. Poniższy tekst jest próbą wyznaczenia miejsca, jakie zajęła hallerowska anatomia animata $\mathrm{w}$ tradycji nauk przyrodniczych, względem wcześniejszych postaw badawczych opisywanych pojęciem anatomia vivorum i fizjologii teoretycznej oraz późniejszej fizjologii eksperymentalnej².

Albrecht von Haller w swoim kanonicznym, ośmiotomowym dziele Elementa physiologiae corporis humani (1757-1766) we wstępie do pierwszego tomu stwierdza, że ktokolwiek chciałby zajmować się fizjologią, musi zacząć od wyjaśnienia natury wewnętrznego ruchu obecnego w organizmach zwierzęcych, funkcji poszczególnych organów, zmian zachodzących w płynach organicznych, a także winien określić siły, dzięki którym życie jest zachowane ${ }^{3}$. Tym samym punktem wyjścia

\footnotetext{
${ }^{1}$ Katedra Historii Medycyny, Coll. Medicum, Uniwersytet Jagielloński, Kraków, e-mail: ryszard.gryglewski@uj.edu.pl, ORCID: 0000-0002-1171-7846.

${ }_{2}^{2}$ Pragnę w tym miejscu podziękować jednemu z recenzentów za wnikliwe i krytyczne uwagi poczynione w stosunku do pierwotnej wersji tekstu, dzięki czemu mogłem dokonać koniecznych w nim uzupełnień.

${ }^{3}$ Na podstawie tłumaczenia S.A. Roe, Anatomia Animata: The Newtonian Physiology of Albrecht von Haller, [w:] Transformation and Tradition in the Sciences: Essays in Honour of I Bernard Cohen, E. Mendhelson (red.), Cambridge 1984, s. 276.
} 
stało się zjawisko ruchu rozpatrywane na gruncie anatomii - anatomia animata, którą Haller uznawał za klucz do zrozumienia fizjologii ${ }^{4}$, wyznaczając jej rolę badania zarówno struktury, jak i przez nią funkcji życiowych organizmus. Było to zgodne z poglądami Hallera, który zakładał, że ruch wywodzi się bezpośrednio z materii, będąc jej stałą cechą. Tym samym postawę szwajcarskiego badacza można określić jako bliską założeniom mechanicyzmu ${ }^{6}$. Dlatego też według niego charakter obserwowanego ruchu powinien być rozpatrywany w kontekście poznawanej struktury, z którą jest związany. W konsekwencji należało przyjąć anatomię jako punkt wyjścia dla wszelkich rozważań w polu fizjologii ${ }^{7}$, a hallerowskie poszukiwania doświadczalne podporządkowane zostały strukturom anatomicznym właśnie ${ }^{8}$. Jest to o tyle zrozumiałe, że w XVIII stuleciu anatomia miała już ugruntowaną pozycję w naukach przyrodniczych, a metodyka badań oparta na sekcjach zwłok i preparatyce była $w$ wysokim stopniu rozwinięta. Fizjologia zaś nadal pozostawała dyscypliną dyskursywną i spekulatywną bliższą intuicjom wypowiedzianym jeszcze w XVI stuleciu przez francuskiego lekarza Jeana Fernela (1497-1558), który twierdził, że anatomia ma się tak do fizjologii, jak geografia do historii - dokonuje opisu zdarzeń9. Fizjologia nie jest zatem odrębnym postępowaniem empirycznym wykorzystującym eksperyment, lecz dążeniem do uporządkowania zaobserwowanych przez anatoma faktów. Dlatego też Haller stosował pojęcie ,anatomii ożywionej”, podkreślając tym samym istotne źródło swoich dociekań naukowych. Taka postawa nie jest niczym niezwykłym i można zgodzić się z Andrew Cunninghamem, który podkreśla, że fizjologia w XVIII stuleciu nie powinna być utożsamiana z późniejszą fizjologią eksperymentalną, której narodzin należy szukać w początkach XIX w. ${ }^{10}$

${ }^{4}$ A. Cunningham, The pen and the sword: recovering the disciplinary identity of physiology and anatomy before 1800. Part I: Old physiology - the pen, „Studies in History and Philosophy of Biological \& Biomedical Sciences” 2002, vol. 33, s. 640. Haller pisał: „Erunt, qui objiciant, meram me scripsisse anatomen. Sed physiologia est animate anatome”. Tegoż, Primae lineae physiologiae, Getynga 1747, s. 5, [za:] https:// archive.org (dostęp: 8.12.2017).

${ }^{5}$ D.E. Wellbery, A New History of German Literature, Harvard 2004, s. 346.

${ }^{6}$ A. Bednarczyk, Spory wokót ogólnych pogladów teoretycznych Albrechta von Hallera (8 X 1708-12 XII 1777): w dwusetna rocznice śmierci, „Kwartalnik Historii Nauki i Techniki” 1978, t. 23, nr 3-4, s. 618.

7 H. Steinke, Irritating Experiments: Haller's Concept and the European Controversy on Irritability and Sensibility, 1750-90, New York 2005, s. 77.

${ }^{8}$ A. Cunningham, dz. cyt., s. 653-654.

${ }^{9} \mathrm{R}$. Shane Tubbs, Anatomy is to physiology as geography is to history; it describes the theatre of events, „Clinical Anatomy” 2015, vol. 28, s. 151.

${ }^{10}$ A. Cunningham, dz. cyt., s. 659. 
Czym zatem jest i jakie miejsce zajmuje anatomia animata w XVIII-wiecznym przyrodoznawstwie? Na te pytania nie ma, jak się wydaje, jednoznacznej odpowiedzi. Niewątpliwie czerpie z kilku źródeł jednocześnie. Jak już stwierdzono powyżej, wyrasta z anatomii i jest de facto jej emanacją. Można też powiedzieć, że jest specyficznym sposobem jej uprawiania, zwłaszcza gdy przywołamy w tym miejscu wiwisekcje. O ile bowiem „klasyczna” anatomia opierała się na badaniu wykonywanym post mortem, o tyle anatomia „żywych organizmów” (anatomia vivorum) sięgała również po badanie wykonywane ante mortem, a głównym jej celem było badanie natury ruchu ${ }^{11}$. Tradycja przypisuje takie właśnie postępowanie starożytnym, a pierwszym, który mógł kroczyć tą drogą, zgłębiając budowę nerwu wzrokowego, był Alkmeon z Krotonu (VI/V w. p.n.e.) ${ }^{12}$. Niewykluczone, że Arystoteles ze Stagiry, Diokles z Karystos i Praksagoras z Kos także wykonywali wiwisekcje na zwierzętach ${ }^{13}$. Wiwisekcje były wykorzystywane $\mathrm{w}$ kolejnym pokoleniu badaczy tworzących słynną szkołę aleksandryjską ${ }^{14}$. Herofilos z Chalcedonu (ok. 335-280 r. p.n.e.) i Erasistratos z Keos (ok. 304-ok. 250 p.n.e.) prócz sekcjonowania ciał zwierzęcych przeprowadzali autopsje zwłok ludzkich. Herofilos miał również uciekać się do wiwisekcji na skazańcach, chociaż ta sprawa budzi nadal szereg wątpliwości ${ }^{15}$. Należy podkreślić, że wszyscy wymienieni byli filozofami poszukującymi w anatomii faktów, które byłyby pomocne w kształtowaniu teorii życia, a zatem fizjologii. Stąd drugim istotnym źródłem „anatomii ożywionej” będą problemy formułowane na gruncie filozofii. Nie inaczej rzecz tę pojmował Galen (129-200). Podążając za Arystotelesem, uznał za nadrzędny teleologiczny model postępowania w objaśnianiu budowy i funkcji organizmów, któremu podporządkował swoje badania anatomiczne ${ }^{16}$. Korzystał przy tym z niemal całej dostępnej mu tradycji szkół filozoficznych i lekarskich, przejmując wiele z dorobku przeszłych pokoleń, w szczególności zaś alek-

${ }^{11}$ D.B. Meli, Early Modern Experimentation on Live Animals, „Journal of the History of Biology" 2013, vol. 46, s. 201.

${ }_{12}$ G.E.R. Lloyd, Methods and Problems in Greek Science: Selected Papers, Cambridge 1991, s. 169-170.

${ }_{13}$ N.H. Franco, Animal Experiments in Biomedical Research: A Historical Perspective, „Animals” 2013, vol. 3, s. 239; doi:10.3390/ani3010238.

${ }^{14} \mathrm{~J}$. Longrigg, Anatomy in Alexandria in the Third Century B.C, „British Journal for the History of Science” 1988, vol. 21(4), s. 455-488 [za:] http://www.jstor.org/ stable/4026964.

${ }^{15} \mathrm{H}$. von Staden, Herophilus: The Art of Medicine in Early Alexandria, Cambridge 1989, s. 138.

${ }^{16}$ W. Szumowski, Historia medycyny filozoficznie ujęta, Kęty 2008, s. 142-143. 
sandryjczyków. Uformowany w takich warunkach system poglądów Galena można określić mianem eklektyczno-syntetyzującego, w którym anatomia miała pełnić rolę rusztowania koniecznego dla kształtowania się fizjologii. I mimo że anatomię oparł na dochodzeniu empirycznym - sekcyjnym i wiwisekcyjnym, to jednak widział w niej jedną $\mathrm{z}$ emanacji sytemu filozoficznego ${ }^{17}$. Dlatego też traktat Galena De usu partium corporis humani należy czytać jako manifestację poglądów filozoficznych co do istotnej organizacji i funkcji życiowych ludzkiego ciała. Stając się na wiele stuleci podstawowym źródłem wiedzy anatomiczno-fizjologicznej, De usu partium ugruntowało również przekonanie o prymacie logicznie prowadzonego wywodu nad bezpośrednim doświadczeniem. Dopiero schyłek wieków średnich i początek epoki odrodzenia miały stopniowo tę sytuację zmieniaćc ${ }^{18}$.

Renesans przyniósł ze sobą ponowne zainteresowanie postępowaniem empirycznym w polu anatomii, co skutkowało wzrostem publicznie wykonywanych autopsji, jak i przywróceniem wiwisekcji, które stały się teraz narzędziem studiów porównawczych anatomii organizmów ante i post mortem ${ }^{19}$. Zwolennikiem i można powiedzieć propagatorem tak pojętej wiwisekcji był włoski anatom Realdo Colombo (1516-1559) ${ }^{20}$. Także Flamandczyk Andrea Vesalius (1514-1564), uzupełniając swoje dochodzenie autopsyjne na ludzkich i zwierzęcych zwłokach, sięgał po wiwisekcje. Ten sposób uprawiania anatomii, który Francis Bacon (1561-1626) określał znanym już mianem anatomia vivorum $^{21}$, znalazł swoje ukoronowanie w pracach Williama Harveya (1578-1657). Wbrew bowiem często powtarzanej opinii, że w słynnym traktacie angielskiego uczonego Exercitatio anatomica de motu cordis et sanguinis in animalibus z $1628 \mathrm{r}$. należy widzieć początki fizjologii eksperymentalnej ${ }^{22}$, jest to $\mathrm{w}$ istocie anatomia oparta na doświad-

17 R.W. Gryglewski, Rola czynników kulturowych w kształtowaniu się badań anatomicznych opartych o autopsję ludzkiego ciała, „Kultura i Historia” 2016, nr 29, s. 1-10 http://www.kulturaihistoria.umcs.lublin.pl/archives/5732 (dostęp: 22.08.2016).

18 Tamże.

19 R.A. Shotwell, The Revival of Vivisection in the Sixteenth Century, „Journal of the History of Biology" 2013, vol. 46, no. 2, s. 172, https://doi.org/10.1007/s10739-0129326-8 (dostęp: 9.06.2013).

20 A. Wear, Medicine in Early Modern Europe, [w:] The Western Medical Tradition: 800 BC to AD 1800, L.I. Conrad (red.), Cambridge 1995, s. 327-329; A. Cunningham, The Anatomical Renaissance: The Resurrection of the Anatomical Projects of the Ancients, Aldershot 1997.

${ }^{21}$ N.H. Franco, dz. cyt., s. 240.

${ }^{22}$ O. Temkin, The dependence of medicine upon basic scientific thought, [w:] The historical development of physiological thought, C.M. Brooks, P.F. Cranefield (red.), New York 1959, s. 5. 
czeniu zmysłów, na co zresztą jednoznacznie wskazują początkowe słowa tytułu. Dla Harveya bowiem eksperyment (experimentum) jest tożsamy z doświadczaniem za pomocą zmysłów, a zatem mieści się $\mathrm{w}$ postępowaniu sekcyjnym i wiwisekcyjnym ${ }^{23}$. Odkrywca układu dużego krążenia krwi był anatomem, uczniem Girolama Fabricia d'Acquapendentego, zwanego Fabrycjuszem (1567-1619), wychowanym na wzorcach włoskiej medycyny i wyrastającym w tradycji filozofii Arystotelesa ${ }^{24}$. Gdy badał budowę i funkcję serca, sekcjonował in vivo zwierzęta zimnokrwiste - węże, żaby, ślimaki, skorupiaki i ryby, gdyż ich serca biły w wolniejszym rytmie niż serca zwierząt ciepłokrwistych. Te z kolei poddawał wiwisekcji dla określenia charakterystyki skurczu i rozkurczu. W trakcie prowadzonych doświadczeń spostrzegł, że serce węgorza może jeszcze przez pewien czas kurczyć się i rozkurczać po oddzieleniu i wydobyciu go z ciała. Był to zatem wręcz klasyczny przykład obserwacji czynionej na gruncie anatomii ożywionej. Metoda, którą przyjął w badaniach nad funkcją serca i jego miejsca w układzie tętniczo-żylnym, była więc oparta na anatomii porównawczej interesujących go struktur, które starał się objaśniać na drodze mechanistycznych podobieństw. Co więcej, jeśli uważnie się przyjrzeć, u Harveya tylko raz możemy spotkać się z obserwacją wraz z towarzyszącym jej pomiarem, gdy starał się wyznaczyć objętość wyrzutową serca ${ }^{25}$. W swoim postępowaniu angielski badacz chętniej używał hipotez i dedukcji niż drogi indukcyjnej, tak często przecież z jego badaniami utożsamianej, ufał logice wewnętrznej swoich wywodów, którą spajały wnioski wyciągnięte na podstawie komparatystyki anatomicznej. Gdy rozważał charakter obserwowanej funkcji, nieodmiennie odnosił się do struktury, przez co wkraczał na teren anatomii funkcjonalnej, nie zaś fizjologii. I to właśnie dzięki wnikliwej analizie strukturalnej poddanej zasadzie celowości Harvey mógł sformułować ostateczne wnioski o fizjologii krążenia krwi. Gdy w pięć lat później, w 1633 r. holenderski uczony Isaac Beeckman (1588-1637) chciał potwierdzić ustalenia Harveya, zaproponował, by żywemu zwierzęciu usunąć fragment odsłoniętej wcześniej żyły i w to miejsce wprowadzić szklaną rurkę. Dzięki temu można by dokonać

${ }^{23}$ A. Cunningham, The pen and the sword: recovering the disciplinary identity of physiology and anatomy before 1800. Part II: Old physiology - the sword, „Studies in History and Philosophy of Biological \& Biomedical Sciences” 2003, vol. 34, s. 60.

${ }^{24}$ P. Fara, William Harvey, an Aristotelian anatomist, „Endeavour” 2007, vol. 31(2), s. 43-44, doi: 10.1016/j.endeavour.2007.05.006 (dostęp: 5.07.2007).

${ }^{25}$ M.T. Ghiselin, William Harvey's methodology in De motu cordis from the standpoint of comparative anatomy, „Bulletin History of the Medicine” 1966, vol. 40, s. 314. 
obserwacji, czy krew żylna płynie od czy też do serca ${ }^{26}$. Był to dopiero początek drogi w poszukiwaniu dowodów popierających ustalenia Harveya, gdyż wątpiących nie brakowało.

Nie negując dorobku nauk przyrodniczych XVII stulecia, w którym kształtują się nośne szkoły jatromechaników i jatrochemików, fizjologia pozostaje nadal nieodrodną córką filozofii i anatomii ożywionej. Dobrą ilustracją tego stanu rzeczy jest wydane w dwóch tomach dzieło Giovanniego Borelliego (1608-1679) De Motu Animalium, postrzegane jako początek biomechaniki ${ }^{27}$. Włoski uczony przedmiotem swoich badań uczynił mechanikę ruchu istot żywych. Na podstawie porównawczych obserwacji różnych gatunków zwierząt i człowieka tworzył matematyczne modele mogące właściwie opisać ich charakterystykę, dużo uwagi poświęcając zjawisku kurczenia się mięśni. Następnie przechodził do rozważań wokół mechaniki wewnętrznej budowy organizmów, zajmując się dynamiką przepływu krwi, istotą pracy serca oraz zjawiskiem oddychania, konstruując $w$ tym celu spirometr. Jednak gdy próbował wyjaśnić fizjologię ruchu, oddawał się spekulacji, twierdząc że wszelkie jego przejawy są skutkiem przemieszczenia się cząstek, które bądź to pozostają ze sobą w kontakcie lub też dopasowują się do siebie wzajemnie. Cząstki te mają zróżnicowane i ściśle określone kształty i są pochłaniane przez narządy za pomocą specjalnych kanałów, których otwory wejściowe przypominają sito, tak by nie dopuścić do przenikania cząstek niepożądanych ${ }^{28}$.

Tymczasem anatomia vivorum przynosiła istotne odkrycia nie tylko w zakresie badania poszczególnych organów, lecz także pozwalała ujawniać te struktury, które były tak delikatne, że łatwo ulegały degradacji po śmierci. Tak właśnie Gasparo Aselli (1581-1626) odkrył drobne naczynia będące częścią układu limfatycznego. Ponad sto wiwisekcji wykonał Francuz Jean Pecquet (1622-1674), by określić rzeczywistą drogę oraz kierunek przepływu chylusu, stosując przy tym skomplikowany system ligatur. Wyniki swoich obserwacji zawarł w traktacie pod jakże wymownym tytułem Experimenta nova anatomica (1653). Wiwisekcję stosował również Marcelo Malpighi (1628-1694), gdy w $1661 \mathrm{r}$. obserwował pod mikroskopem przeciwny

26 M.J. van Lieburg, Isaac Beeckman and his Diary-Notes on William Harvey's Theory on Blood circulation (1633-1634), „Janus” 1982, vol. 69, s. 161-183.

27 P. Maquet, Iatrophysics to biomechanics. From Borelli (1608-1679) to Pauwels (1885-1980), „Bone and Joint Surgery: British Orthopaedic Association” 1992, vol. 74, s. 335, https://online.boneandjoint.org.uk/doi/pdf/10.1302/0301-620X.74B3.1587872 (dostęp: 3.07.2016).

${ }_{28}$ D.B. Meli, dz. cyt., s. 203. 
ruch krwi w tętnicach i żyłach płucnych u żab. Prowadziło to w konsekwencji do odkrycia nowej struktury anatomicznej - naczyń włosowatych. Ostateczne rezultaty swoich badań opublikował w $1663 \mathrm{r}$. w tekście zatytułowanym De pulmonibus observationes anatomicae.

Mając to wszystko na uwadze zrozumiałe stają się słowa francuskiego badacza Felixa Vicq d'Azyra (1746-1794), który pisząc o fizjologii w początkach XVIII stulecia, tak rzecz tę ujmował: „A commencement de ce siecle la Physiologie n'etoit encore qu'un vain assemblage de systems" ${ }^{29}$. Sam będąc wybitnym anatomem, wskazywał na Hallera jako tego, który pierwszy uczynił fizjologię „nową nauką”, która poza nazwą miała niewiele wspólnego ze starą fizjologią ${ }^{30}$. To, co wyróżniało prace Hallera od poprzedników i wielu jemu współczesnych, to deklarowana potrzeba oparcia każdego postepowania fizjologicznego na dowodach płynących wyłącznie z obserwacji anatomicznych i pozbyciu się wszelkich spekulacji czy z góry powziętych przekonań. Celem autopsji wykonywanej na zwłokach czy też in vivo nie może być tylko potwierdzenie lub zanegowanie obrazu stworzonego przez poprzedników, lecz także poszukiwanie nieznanych dotąd struktur i wynikających z nich mechanizmów. Tak jak anatomia jest nauką empiryczną, tak samo złączona $\mathrm{z}$ nią fizjologia musi polegać wyłącznie na empirii. Aby zostać fizjologiem, trzeba być najpierw anatomem $^{31}$ ergo praktykiem, a nie teoretykiem ${ }^{32}$. Haller wprost twierdził, że głównym źródłem błędów w fizjologii był fakt, że większość lekarzy nie przeprowadzała żadnych doświadczeń (experimentum) lub wykonywała ich zbyt mało lub zbyt rzadko zadowalając się wnioskowaniem $\mathrm{z}$ analogii ${ }^{33}$. Fałszywy obraz wynika bowiem $\mathrm{z}$ pokusy czynienia generalizacji opartych na szeregu obserwowanych przypadków, które uznajemy za prawdziwe dla wszystkich interesujących nas zjawisk, mimo że w istocie niedane nam było poznać natury ich wszystkich ${ }^{34}$. Warto przy tym zauważyć, że pod pojęciem eksperymen-

${ }^{29}$ F. Vicq d'Azyr, Traité d'anatomie et de physiologie, avec des planches coloriées représentant au naturel les divers organes de l'homme et des animaux, Paris 1786, vol. 1, s. 3, http://digi.ub.uni-heidelberg.de/diglit/vicqdazyr1786bd1/0015 (dostęp: 24.06.2017).

${ }^{30}$ F. Vicq d'Azyr, dz. cyt.

${ }^{31}$ A. Cunningham, The pen and the sword..., dz. cyt., Part I, s. 651.

32 A. Bednarczyk, dz. cyt., s. 605.

${ }_{33}$ A. von Haller, A dissertation on the sensible and irritable parts of animals, trans. O. Temkin, „Bulletin of the History of Medicine” 1936, vol. 4, s. 651-699.

${ }^{34}$ Von Haller zapytuje: „Wahrum irreten wir? Wir haben viele Fälle stehn, und schossen auf alle, ohne alle gesehn zu haben”. Tenże, Briefe über die wichtigsten Wahrheiten der Offenbarung, Bern, Buchhandlung 1773, s. 45. 
tu Haller rozumiał znane już metody postępowania badawczego, jakimi była obserwacja, sekcje i wiwisekcje oraz wykorzystanie anatomii porównawczej ${ }^{35}$. Innymi słowy, w tym ostatnim względzie hallerowska anatomia animata podąża przetartym przez anatomia vivorum szlakiem. Uczony wzbogaca jednak tę podróż o konieczne, jego zdaniem, uzupełnienie wiedzą z zakresu chemii i fizyki, a ponieważ punktem wyjścia dla niego, o czym już była mowa, jest ruch, zatem mechaniki i hydrauliki w odniesieniu do badań nad cieczami organicznymi. Tym samym fizjologia staje się teorią ruchu w maszynach „ożywionych”36. Nade wszystko całe postępowanie wymaga czasu i wielokrotnego powtarzania doświadczeń. Bowiem tylko na tej drodze możemy potwierdzić lub wykluczyć prawdziwość badanych zjawisk, a eksperyment staje się ważnym narzędziem badawczym ${ }^{37}$. Nie ulega też wątpliwości, że Haller rozumiał znaczenie strony technicznej eksperymentów, podkreślając, że coraz lepsze przyrządy znaczą więcej niż wyobraźnia i erudycja filozofów $w^{38}$.

Jest to bez wątpienia nowe spojrzenie na fizjologię i trudno się dziwić hołdowi Felixa Vicq d'Azyra złożonemu dokonaniom Hallera. Należy jednak podkreślić, że anatomia animata nie może być utożsamiona z physiologia experimentalis, i że ta druga różni się od tej pierwszej w zasadniczy sposób. Haller bowiem nie zdołał się uwolnić od charakterystycznej przez całe stulecia relacji, w jakiej znajdowały się anatomia i fizjologia. Aktywne działanie przy stole sekcyjnym, preparowanie i utrwalanie przy pomocy wosku barwionego lub rtęci badanych struktur, porównawcze ich zestawianie, wreszcie opis zaobserwowanych mechanizmów przynależą do anatomii. Fizjologia Hallera jest w swej istocie nadal pasywna, wykorzystująca szczegółowo opracowany przez anatoma materiał dla konstruowania modeli teoretycznych. Jak to ujął przywoływany już Cunningham: „It is still theoretical physiology built upon investigative (experimental) anatomy; it is still science built on art"39.

Hallerowska anatomia animata budziła podziw swoim rozmachem, pomysłowością, szczegółowością oraz rzetelnością prezentowanych wyników badań. Jego Primae Lineas Physiologiae (1747), a zwłaszcza

${ }^{35}$ S.A. Roe, dz. cyt., s. 274.

${ }^{36}$ F. Duchesneau, Physiological Mechanism from Boerhaave to Haller, „Man and Nature" 1982, 1, s. 214, doi: 10.7202/1011804ar.

${ }^{37}$ A. Bednarczyk, dz. cyt., s. 606.

${ }_{38}$ A. Roe, Matter, Life, and Generation: Eighteenth-Century Embryology and the Haller-Wolff Debate, Cambridge 2003, s. 95.

${ }^{39}$ A. Cunningham, dz. cyt., s. 656. 
ośmiotomowa Elementa Physiologiae Corporis Humani (1757-1765) bez wątpienia stały się jednymi z najważniejszych prac XVIII-wiecznej medycyny. To właśnie na kartach tej drugiej Haller zawarł pierwszą tak głęboką analizę historii badań w zakresie fizjologii. Znajomość wszelkich dostępnych mu źródeł stanowiła podstawę dla konfrontacji teorii głoszonych przez innych $\mathrm{z}$ obserwacjami czynionymi w obszarze anatomia animata. By sprostać temu zadaniu, ten wychowanek lejdejskiej szkoły Boerhaavego stworzył przy uniwersytecie w Getyndze, gdzie w latach 1737-1753 był profesorem, instytut anatomiczny, wokół którego zdołał zgromadzić liczne grono uczniów ${ }^{40}$. To tu też wypracowano stały schemat badań: wielostopniowych i wielokrotnie powtarzających się w licznych modyfikacjach, z wykorzystaniem postępowania mikroskopowego. Jeden z twórców fizjologii eksperymentalnej François Mangendie (1783-1855) twierdził później, być może z pewną przesadą, że ilekroć był przekonany, że opracował nowy eksperyment, ku swojemu niemiłemu zaskoczeniu odnajdował ten sam pomysł w pracach Hallera ${ }^{41}$.

W podsumowaniu można powiedzieć, że anatomia animata, chociaż zakotwiczona w tradycji anatomia vivorum, przynosiła ze sobą nową propozycję badawczą. Nie tyle w definiowaniu struktury doświadczenia (experimentum), które w sumie zachowało te same, co wcześniej, elementy składowe, ile w intensywności i powtarzalności jego zastosowania. Haller, dążąc do tego, by fizjologię „oczyścić” ze spekulacji i błędów wynikających z wyciąganiu wniosków per analogiam, odwoływał się do eksperymentu anatomicznego jako jedynej dostępnej mu wówczas drogi postępowania empirycznego na gruncie nauk przyrodniczych. I chociaż tym samym utrwalał stary schemat zależności fizjologii od anatomii i sam nie był wolny od „grzechu spekulacji”, to jednocześnie wskazywał na konieczność gruntownego przekształcenia tej pierwszej. Niewątpliwie był to ważny krok w kierunku „nowej” fizjologii.

Claude Bernard, który w Hallerze widział pioniera metody eksperymentu bezpośredniego ${ }^{42}$, jasno zdefiniował różnicę, jaka dzieli sposób widzenia anatoma i fizjologa eksperymentalnego:

Le physiologiste suit encore une idée différente de celle de l'anatomiste; ce dernier, ainsi que nous l'avons vu, veut déduire la vie exclusive-

${ }^{40}$ H. Steinke, dz. cyt., s. 51-54.

${ }^{41}$ L.N. Magner, A History of the Life Sciences, Revised and Expanded, New York 2005, s. 186.

${ }^{42}$ C. Bernard, Leçons sur les propriétés des tissus vivants, Germer Bailliére, Paris 1866, s. 71. 
ment de l'anatomie; il adopte, par conséquent, un plan anatomique. Le physiologiste adopte un autre plan et suit une conception différente: au lieu de procéder de l'organe pourarriver à la fonction, il doit partir du phénomène physiologique et en rechercher l'explication dans l'organisme ${ }^{43}$.

Była to już jednak inna epoka.

\section{Summary In-between of anatomia animata and physiologia experimentalis}

The Swiss scholar, Albrecht von Haller (1708-1777), when proposing a new model of physiology as an empirical science, not a speculative one, has turned to the already established anatomical methodology, thus giving rise to the anatomia animata - animated anatomy. The subject of this study is to determine the place that the hallerian anatomia animata took in relation to the anatomia vivorum and theoretical physiology as well as later experimental physiology.

Keywords: History of anatomy; history of physiology; anatomia animata; Albrecht von Haller

${ }^{43}$ Tenże, Introduction à l'étude de la médecine expérimentale, Paris 1865, s. 194. 